Annals of Plant Sciences

ISSN: 2287-688X

OPEN ACCESS

www.annalsofplantsciences.com

Research Article

\title{
Taxonomical note, new distributional record and traditional use for Dioscorea wallichii Hook. f. (Dioscoreaceae) of Tripura North-East India
}

Chiranjit Paul, Amal Debnath, Rahul Chanda, Bimal Debnath*

Department of Forestry and Biodiversity, Tripura University, Suryamaninagar-799022, Tripura, India.

Received: 2017-11-08; Accepted: 2017-11-19

\begin{abstract}
The existence of Dioscorea wallichii Hook. f. (Dioscoreaceae) is noted first time from the forest floor of Tripura, North East India. The tuber of this plant is used as a vegetable as well as a medicinal purpose by the indigenous peoples of the state. Reang communities of Tripura used tuber of this plant for stomach pain and Jamatia community have eaten this tuber with honey for refreshment and also increase physical fitness. It is widely distributed throughout forest floor as well as the degraded land of the state.
\end{abstract}

Keywords: Dioscorea wallichii, Taxonomy, new distributional record, Ethnobotany, IUCN status, Tripura

\section{Introduction}

Dioscorea L. is a herbaceous mono-cotyledonus genus of over 600 species (Ayensu 1972) grown up to 20 meters on supports. The genus belongs to the family Dioscoreaceae produce starchy edible tuberous roots that are very important source of food in tropical regions worldwide. Dioscorea is native in the tropical and subtropical region of the world, only a few species found in the temperate region (Caddick et al., 2002; Seikh et al., 2009). In India 50 species of Dioscorea have been reported by the Prain \& Burkill 1936. According to previous report 10 species of Dioscorea (Deb 1983; Majumder et al., 2009; Paul et al., 2014; Debnath et al., 2015) found in Tripura Viz. D. alata Linnaeus, D. bulbifera var. bulbifera Linnaeus, $D$. bulbifera var. sativa (Hooker f.) Prain, D. glabra Roxburgh, D. hamiltonii Hooker f., D. pentaphylla Linnaeus, D. pubera Blume. D. hispida Dennsted, D. oppositifolia L., Dioscorea esculenta (Lour.) Burkill var. spinosa R. Knuth. A large amount of extensive survey in the different part of Tripura some species of Dioscorea has been collected by the authors which were later on identified as Dioscorea wallichii Hook. f. whereas the occurrence of this species and its uses in Tripura was unknown before its present collection.

Tripura, the East Himalayan foothill state of India covering 10,491 $\mathrm{km}^{2}$ area, is the homeland of 19 primitive groups which comprises $33 \%$ of the state population $(36,710,321)$ [Census 2011]. The state lies between $22^{\circ} 56^{\prime}$ to $24^{\circ} 32^{\prime} \mathrm{N}$ latitude and $90^{\circ} 09^{\prime}$ to $92^{\circ} 30^{\prime} \mathrm{E}$ longitudes, where $60 \%$ of the area is covered by forest. The temperature of this region ranges from $7^{\circ}$ to $37^{\circ} \mathrm{C}$ with $220 \mathrm{~cm}$ of average rainfall. The total forest cover in the State is $6292.681 \mathrm{~km} 2$ which are approximately $60 \%$ of the

*Corresponding Author:

Dr. Bimal Debnath,

Department of Forestry and Biodiversity,

Tripura University, Suryamaninagar-799022,

Tripura, India.

E-mail: bimalbiotech2012@gmail.com total area of State is under the forest cover encompassing of tropical forest trees (including rubber and bamboo). Due to its tropical geographical position and favorable environmental condition, Tripura is too rich in terms of its floral and faunal diversity. The recent change in the climate and forest structure due to the speedy expansion of rubber plantation it is very important to update and revise the existing floral diversity of the state because Climate change and forest structure play a key role in defining the function and distribution of plants.

\section{Materials and Methods}

An ethno-medicinal inspection was conducted in the different parts of Tripura for gathering information about ethno-medicinal practices of medicinal plants used by the different ethnic communities of Tripura. During data collection 2014-2017 the plant was collected and identified based on critical taxonomic studies and matches with the various flora and plant database (eflora of China, Global plant Database, Kew Database, The plant List). The specimens were matched with the Kew herbarium catalogue - online database, specimen number of the matched sheet is K000401052. Fresh and mature plant parts including flowers, fruits, and tubers were collected from the field. Specimens were made into herbarium sheets following Jain \& Rao (1977) and deposited at the Herbarium of the Department of Forestry and Biodiversity, Tripura University. The collected tubers were planted in the experimental garden at Tripura University campus for further observation. 

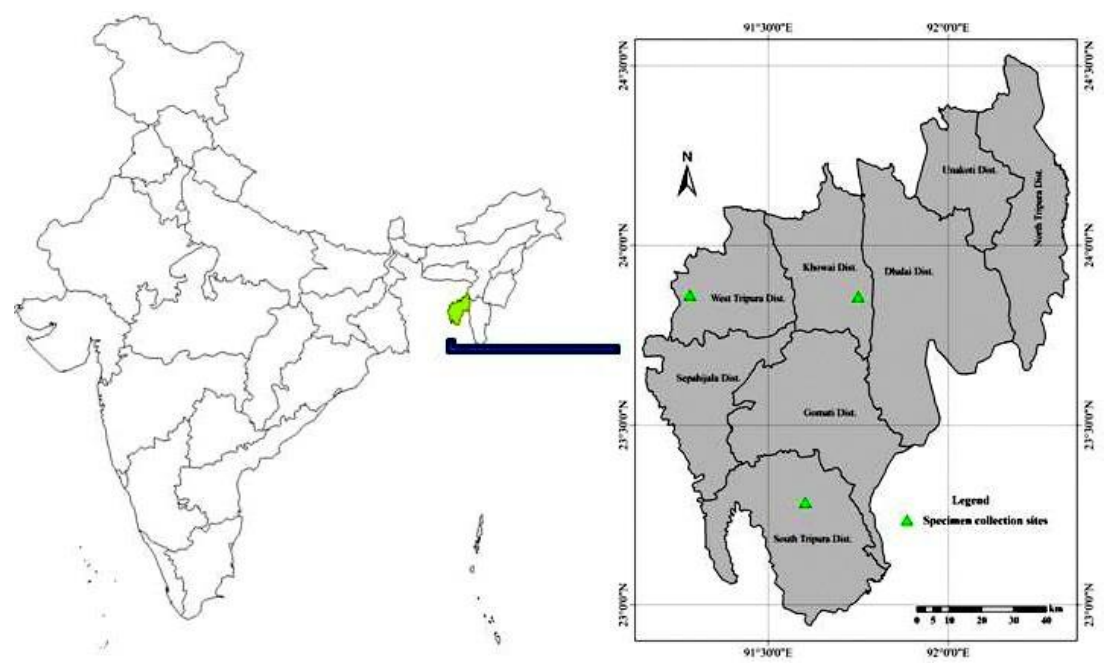

Figure 1: Specimen collection site.
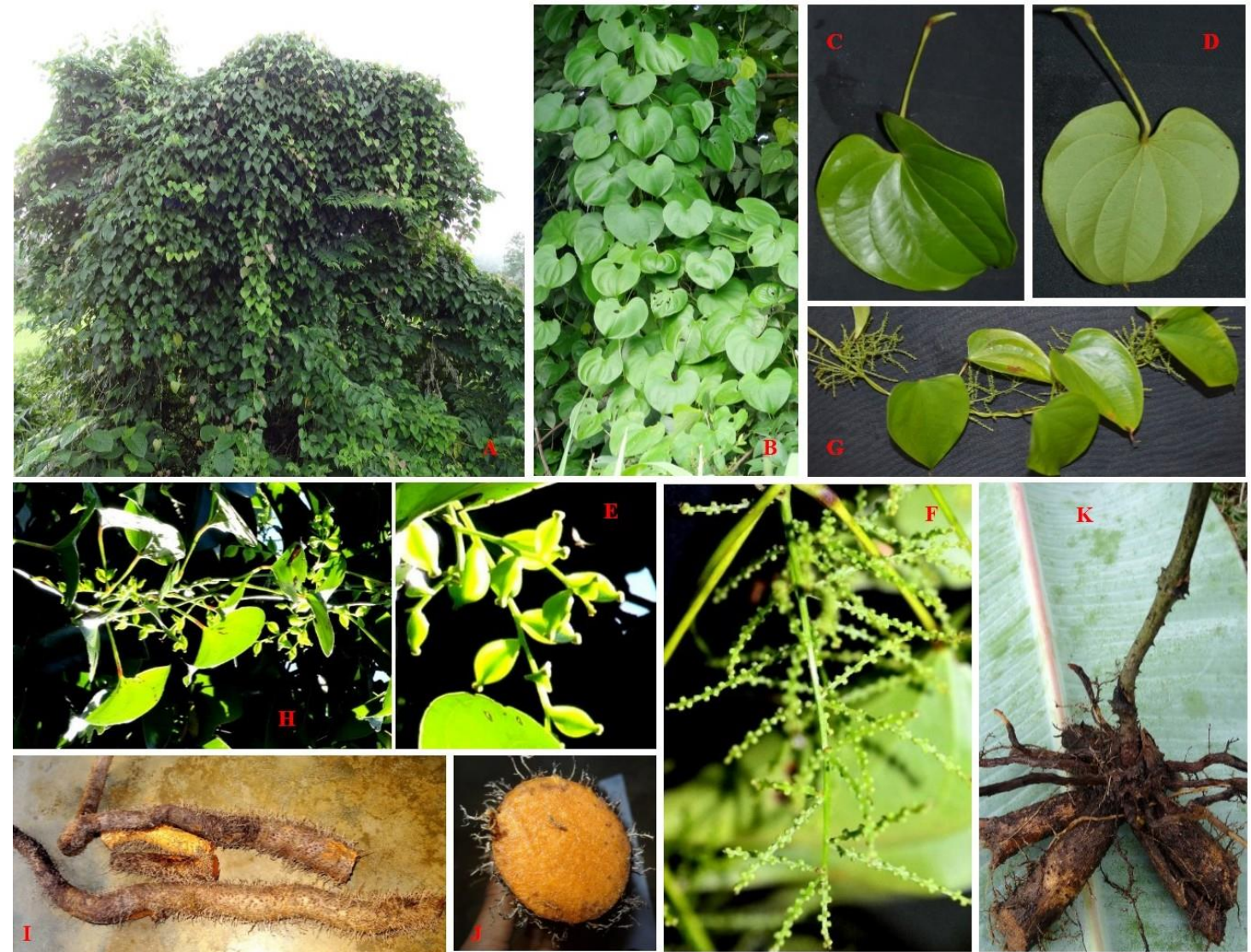

Plate 1: Figure A and B- Natural habitat of Dioscorea wallichii plant; C- Upper surface of Leaf; D- Lower surface of Leaf; E- Fruit; H- Female inflorescence; G,F- Male inflorescence; I- Tuber; J- inner view of tuber; K- Showing woody stem with spines at the base.

Taxonomic treatment

Dioscorea wallichii Hook. f., Fl. Brit. India 6: 295.1892; Rao \& Verma, Bull. Bot. Surv. India 15:200. 1973.

Synonyms: Dioscorea wallichii var. christiei Prain \& Burkill, Dioscorea wallichii var. vera Prain \& Burkill

\section{Vernacular name:}

Gulogaya (Bhil), Khirsaaalo (Chakma), Kaifal (Darlong), Ganggalotha, (Debbarma), Tekpok (Halam), Mayonmokoi (Jamatia), Rokkon (Kuki),
Changpoa (Mog), Beng Kanda (Munda), Ganga lotha (Murasing), Ganga lotha (Noatia), Ganga (Reang), Goa (Tripuri)

Tuber cylindrical palmately branched about $1 \mathrm{~m}$ long and $3-7 \mathrm{~cm}$ wide. The tuber is white when young it becomes yellow and blackish when aged, bearing dark spots and numerous dark branched hairs. The flesh color of the tuber is light yellow and highly fibrous. Bulbil absent, Stem round, twining 
to right, glabrous, woody and armed with spines at the base whereas the upper regions are without spines. The young leaves are of different shades, varying from purplish green, light green or dark purple. Mature leaves simple, opposite or alternate, green, glabrous. Margin entire, cordate, apex caudate. Leaves are usually 8-19 × 6-16 cm and more or less heart-shaped, with 7-9 veins. Petiolate, petiole size $5-11 \mathrm{~cm}$, petiole base swollen, purple ring present at both the end of the petiole, glabrous, green in colour. Leap tip size $0.5-1 \mathrm{~cm}$, color light gray with the blackish spot. $D$. wallichii has separate male and female plants. Male inflorescence spike, 3$6 \mathrm{~cm}$. Male flower bracts with a purplish red spot in perianth, stamens 6 . Female flower perianth, fleshy. Fruits capsules, brown seeds, each with a thin, marginal wing.

Flowering and fruiting: October-December Habitat and Ecology: D. wallichii is a climbing tuberous plant which grows on numerous large shrubs or trees in mixed deciduous forests, also occurs in disturbed areas along roadsides and margins of cultivated areas.

Geographic Range: Dioscorea wallichii is distributed from India to China and to Peninsula Malaysia (IUCNREDLIST, 2009)

Countries occurrence: Bangladesh; China; India; Malaysia (Peninsular Malaysia); Myanmar; Thailand (IUCNREDLIST, 2009)

Red List Category \& Criteria: $D$. wallichii is commonly extensive in its natural range. The population is presently believed to be stable and no major threats are known at present. It appears to be tolerant of some disturbance judging from the areas where it is found. Hence the species is listed as Least Concern ((IUCNREDLIST, 2009)

Status: Available throughout the state

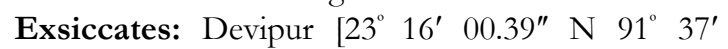
49.84" E], C Paul FBD-038, December 10, 2016;

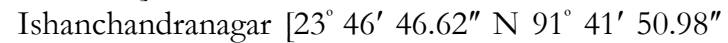
E, C Paul FBD- 079, September 5, 2017]; Kulai R.F $\left[23^{\circ} 53^{\prime} 05.07^{\prime \prime} \mathrm{N} 91^{\circ} 48^{\prime} 15.52^{\prime \prime} \mathrm{N}\right]$, C Paul FBD083, October 10,

Vegetable use: Young aerial shoot and Soft part of tuber are used as a vegetable by most of the ethnic communities of Tripura.

Ethno-medicinal use: Powdered tuber is mixed with honey and taken orally for refreshment and to increase physical fitness 'Janmatia' tribe of Roiswabari forest tract near Dumbur lake and Reang communities of Tripura used tuber for stomach pain.

\section{Conclusion}

The present study revealed that the aerial shoot and tubers of Dioscorea wallichii Hook.f. is used as a vegetable as well as traditional medicine by the different tribal inhabitants of Tripura. This species is very important for the seasonal food security and also from the medicinal point of view at least in this remote North-Eastern Indian state. The collection of the species from the state is an addition to the flora of Tripura state. The species need to be studied for its nutritional qualities and domestication.

\section{Acknowledgement}

The authors are gratitude to CSIR for providing a grant [Sanction letter No. 38(1371)/13/EMR-II] which helped us to carry out this work.

\section{References}

1. Ayensu ES. Anatomy of the monocotyledons, Vol. VI. Dioscoreales. Oxford Press, Oxford, 1972, 182

2. Caddick LR, Rudall PJ, Wilkin P, Hedderson TAJ and Chase MW. Phylogenetics of Dioscoreales based on combined analyses of morphological and molecular data, J. Linn. Soc. (Bot.), 2002, 138, 123 144.

3. Census of India Provisional population totals figures at a glance, Tripura, 2011. Available at: www.tripurainfo.com/info/ATripura/census11.htm.

4. Contu S. Dioscorea wallichii. The IUCN Red List of Threatened Species 2009: e.T165731A6103873, 2009.

5. Deb DB. The Flora of Tripura state, Vol. 2. Today \& Tomorrows' Printers and Publishers, New Delhi, 1983, $417-422$.

6. Debnath, B. Paul, C. and Debnath, A. Dioscorea esculanta (Lour.) Burkill var. spinosa R. Knuth, [Dioscoreaceae] - A new distributional record for Tripura, India, Global Bioscience, 2015, 4(7), 28692872.

7. Flora of China. Vol 24. pp-29. www.eforas.org

8. Global plant Database. https://about.jstor.org/whats-in-jstor/primarysources/global-plants/

9. Jain, S.K \& R.R. Rao. A Handbook of Field and Herbarium Methods, Today and Tomorrows' Printers and Publishers, New Delhi, 1977.

10. Kew Database. http://specimens.kew.org/herbarium/K000401052

11. Majumder K, Saikia B and Datta BK. A new recorded for Tripura, India (Dioscorea hispida Dennst.), Pleione, 2009, 3(2), 224 - 226.

12. Paul C, Debnath A and Debnath B. Dioscorea oppositifolia Linnaeus [Dioscoreaceae] - a new distributional record for Tripura, India, Pleione, 2014, 8(1), $184-187$.

13. Prain D and Burkill IH. An account of the genus Dioscorea in the East. Annals of the Royal Botanical Gardens, Culcutta. Longman, London, 1936.

14. Seikh N, Kumar Y, Misra AK and Pinokiyo A. Status documentation of Dioscorea L. 
(Dioscoreaceae) in Meghalaya: an approach towards food security, Pleione, 2009, 3(1), $74-82$.

15. The plant List.

http://www.theplantlist.org/tpl/record/kew$\underline{241143}$

16. Tropicos.

http://www.tropicos.org/NameSearch.aspx?name= Dioscorea + wallichii

\section{Cite this article as:}

Chiranjit Paul, Amal Debnath, Rahul Chanda and Bimal Debnath. Taxonomical note, new distributional record and traditional use for Dioscorea wallichii Hook. f. (Dioscoreaceae) of Tripura North-East India. Annals of Plant Sciences 6.12 (2017) pp. 1868-1871.

doi: http://dx.doi.org/10.21746/aps.2017.6.12.11

Source of support: CSIR, India.

Conflict of interest: $\mathrm{Nil}$ 